\title{
The Sages as Bible Critics
}

\author{
Yehuda Brandes
}

\section{The Critical Reading of the Bible}

Devoutly religious Jews, even if they have never heard of biblical criticism or ventured outside the confines of traditional Torah study, are proficient in the critical reading of the Bible. Because strict adherence to the simple meaning of the biblical text is impossible, the reader cannot merely accept the text as it is written, and must therefore examine it critically. If under examination, the text appears to contradict reality, other verses, or reason, it must be stripped of its simple meaning and interpreted appropriately. The traditional Hebrew term for biblical criticism is "midrash" - the diametric opposite of a fundamentalist reading of the Bible that adheres to the literal meaning of the text.

The Jewish encounter with Islam in the gaonic period generated a revolutionary trend toward studying the Bible according to its plain meaning. This deviation from the traditional method of bible study, rabbinic midrash, was influenced by Muslim literal interpretation of the Quran that also inspired the Karaite Jews. Rabbinic scholars were forced to make use of contemporary intellectual and hermeneutic tools in order to defend the traditional faith and halakhah. ${ }^{1}$

Notwithstanding the opinion of early academic scholars of Judaism, the traditional midrashic method of studying the Bible developed by the sages is actually closer to modern biblical criticism than the method of the peshat (literal or contextual) exegetes of the Middle Ages, because it allows a wider range of possible interpretations. ${ }^{2}$ The sages already posed all the questions later raised by biblical critics. Moreover, they enjoyed more intellectual freedom than traditional commentators of the modern period because, unlike the later, they did not have to face refutations of the sanctity of the Bible and the consequent challenges to Jewish religious belief. ${ }^{3}$ The faith of the sages was neither 
based on the belief in the sanctity of each letter of the biblical text, nor on the sanctity of the books of the Bible or their historical validity. The sages themselves, in the beit midrash, endowed these books with authority and sanctity. They determined which books were to be left outside the canon, and forbad Jews to read them. ${ }^{4}$

Critical analysis is based on three parameters: text, language, and history. ${ }^{5}$ The sages worked intensively in each of these fields. In the field of textual analysis, they counted the words and letters in the Bible, ${ }^{6}$ compared the texts of the Torah scrolls kept in the Azarah of the Temple to the text of other scrolls, ${ }^{7}$ pointed out variations between what they referred to as "our Torah" and the "Torah of Rabbi Meir," ${ }^{8}$ and were aware of the discrepancies between the Septuagint and the traditional text, ${ }^{9}$ inter alia.

In the field of linguistics, the sages used words from Greece, ${ }^{10}$ Syria, ${ }^{11}$ Africa $^{12}$ and Arabia ${ }^{13}$ in order to explain unclear words in the Bible. ${ }^{14}$ They were aware of differences between biblical and mishnaic Hebrew, ${ }^{15}$ and the difficulties inherent to every attempt to translate the Bible to other languages. ${ }^{16}$ Above all, their sensitivity to language is expressed in the midrashic interpretations of words and verses, and the connections they made, through linguistic tools, between different subjects and places in the Bible.

The sages also discussed the historical context of the biblical texts. To this end, they attempted to construct an outline of world history from creation until their own time, based on the Bible, tradition, and the few external sources available to them. ${ }^{17}$ They had neither significant, reliable, external historical sources nor modern historical methodology. This did not, however, prevent them from meticulously examining the information they did have, or attempting to place each source in its historical context to the best of their abilities and in their own way.

It is customary to divide biblical criticism into two categories: "lower" or "textual" criticism examines the accuracy of the text, word for word, while "higher" or "literary" criticism examines the characteristics of the books, their authors, sources, editing, and time of completion. ${ }^{18}$ The sages engaged intensively in both these fields. They analyzed the language of the Bible to the letter: "the early sages were called sofrim ["scribes," but also "counters"] because they counted all of the letters in the Torah." ${ }^{19}$ They also investigated the literary sources of the Bible and its redaction, editing, and canonization. The purpose of this article is to bring to light classical rabbinic sources which can validate and legitimatize modern biblical scholarship. 


\section{The Sages and Modern Scholarship}

There is no fundamental difference between the sages and critical Bible scholars in their approach to asking questions, an approach that contrasts with the fear of heretical inquiry characteristic of the "faith-based" or haredi approach to Bible study. ${ }^{20}$ The sages developed defense mechanisms against heretical questions. Sometimes the question was put in the mouth of a heretic, ${ }^{21}$ a Roman matron, ${ }^{22}$ or a wicked gentile. ${ }^{23}$ Sometimes the sages used a strategy of dual interpretation: they answered the annoying questions of heretics and gentiles polemically, but responded to their students, the audience within the beit midrash, in a different way. ${ }^{24}$ In general, it was the sages' policy to differentiate between what they taught in the beit midrash and what they taught in a public forum comprised of the less-sophisticated and less-learned general public. ${ }^{25}$ However, they did not refrain from raising even the most difficult questions in the beit midrash.

Precedents can also be found in rabbinic literature that can legitimize all of the methods used by modern biblical scholarship to find answers to their questions: linguistics (including analyses of both Hebrew and other languages), textual emendations, source criticism, dating, historical identifications, the use of the sciences and external literature-all these exist in classical rabbinic literature. Although the frequency of use, the database, and the methods differ from those of modern scholarship, there are enough examples to prove that the sages authorized the use of these methods in their beit midrash.

The approach of the sages differs from that of modern scholarship in three major aspects. These differences do not challenge the legitimacy of modern scholarship, but demand clarification and a precise understanding of the reason for the gaps and the way of bridging them.

The first difference is methodology. The tools available to the modern Bible scholar, such as archeological, historical, linguistic, and cultural information, and methods of literary analysis, were not available to the sages. However, the absence of these tools in the past does not invalidate their use in the future. ${ }^{26}$

The second difference is the sanctity of the texts. The sages regarded the Bible as a divine, holy source, and its study as the fulfillment of a commandment. They looked upon it as an authoritative source for beliefs and opinion and halakhic practice. The modern critical scholar usually views the Bible, at best, with academic dispassion, and, at worst, as a means to justify 
his belief system, which differs from that of the sages. At its inception, biblical scholarship served the aims of Christian theology and, later, of atheism. ${ }^{27}$ When Orthodox Jews began to confront biblical criticism they were unable to change the preexisting skepticism towards it among religious Jews. Although these are indeed valid arguments against both the scholars and their biased and misleading scholarship, ${ }^{28}$ they do not delegitimize critical Bible study itself. ${ }^{29}$ One has to know how to discard the peel of the pomegranate and eat its seeds, as Rabbi Meir did with the teachings of his master, the heretic Elisha ben Abuya. ${ }^{30}$

The third difference concerns the relationship between peshat (plain, contextual meaning) and derash (homiletic or creative interpretation). The modern scholar thinks that he must find religious answers to his critical questions by means of peshat exegesis. In contrast, the sages believed that answers to critical questions should be proposed by means of derash. ${ }^{31}$ Like the Karaites, critical biblical exegetes since Spinoza based their faith on peshat, while the critical exegetes among the sages based their faith on a tradition that is not dependent on the plain meaning of the biblical texts, and interpreted the texts in accordance with their accepted beliefs and opinions.

In this respect, the contemporary naïve believer and nonbelieving biblical scholar are similar to each other, and different from the sages. Both believe that faith is founded upon the simple meaning of the biblical text. The scholar reasons that if he proves that the Red Sea did not part as the text describes, either by directly challenging the historical/scientific validity of the story or by eroding the credibility of the storyteller through literary devices, he will undermine the purity of faith. The naïve believer is likewise apprehensive that if he is confronted with difficult questions about the simple meaning of the biblical narrative of the parting of the Red Sea, his faith will be uprooted.

In contrast, the sages did not fear contradictions between the simple meaning of the text and their beliefs. For example, when faced with difficult discrepancies between the book of Ezekiel and commandments in the Torah, they considered the possibility of excluding the book from the canon. In the end it was canonized, after the contradictions were reconciled by this interpretative project. ${ }^{32}$ This decision to retain the book of Ezekiel was faith based and entirely unrelated to the straightforward interpretation of the text. The believing Bible scholar of today should follow this path-to remain attentive to the contextual meaning of the text, as it appears, and resolve his crises of faith by means of midrash. 


\section{Peshat and Derash}

Modern scholarship is interested in the peshat. In this respect, it follows in the footsteps of both the greatest of the medieval rabbis and the modern scholars of philology and hermeneutics, who regarded the peshat as the direct path to understanding the early sources. ${ }^{33}$ For the purpose of this discussion, I will define peshat as reading the text in its context, as it was written by its author at the time of its composition, in an attempt to understand the meaning of the words intended by their author and understood by those who heard or read them for the first time. Derash attempts to infuse the text with additional meanings. It is possible that these meanings were already latent within it, though not apparent on its most basic and obvious level. ${ }^{34}$ It is also possible that these meanings were hidden from the listeners and readers of the text and from its author, even if he was a prophet. ${ }^{35}$

The sages did not disapprove of peshat. They wanted to find the reason and purpose in the simple meaning of the text. The question, "What is the peshat of the text?" is repeated in several places in the Talmud where a verse is interpreted by means of derash. ${ }^{36}$ They did not, however, consider the peshat to be the most important meaning of the text and certainly not its exclusive meaning. It would be more accurate to say that they presented the peshat as a secondary option in the interpretation of Scripture. In certain sources it appears that the sages regarded the peshat itself as a kind of derash. There were sages who expressed excitement over the new insights revealed to them by a peshat reading of the text, as opposed to the traditional midrashic reading with which they were familiar. ${ }^{37}$

The sages were well aware that the simple meaning of the words "eye for eye" (Exod. 21:24) is "an actual eye." However, because the accepted halakhic tradition holds that monetary compensation was sufficient, the Gemara presents nine different justifications for the deviation from the actual meaning of the words. Even the opinion of Rabbi Eliezer, "eye for actual eye," was shorn of its literal meaning and his words were interpreted to mean that he agreed that the verse refers to monetary compensation but argued that the simple meaning of the verse has implications regarding the nature of this compensation. ${ }^{38}$

\section{The Purpose and Method of Midrash}

The accepted understanding of the need for midrash is influenced by the perspective of peshat exegesis. It is naively assumed that the purpose of the midrash is to resolve difficulties in the text. There are midrashim that grew out 
of exegetical questions, such as a contradiction between verses. Other midrashim bridge the gap between the sages' worldview and the plain meaning of the text. However, in truth, derash interpretation is not primarily a means of solving exegetical difficulties, but a way of studying the Torah that enriches and expands. The underlying assumption of derash is that the Torah was given for this very purpose - so that its students will reveal the various possible perspectives within it, and even read external insights and ideas into its verses. ${ }^{39}$ Structurally speaking, a midrash will often ostensibly open with an exegetical question, but the problem raised is merely a means to arrive at the midrashic saying. Occasionally, from a strictly exegetical perspective, it would be possible to suggest a simple and easy answer, yet the commentator prefers a convoluted explanation far removed from the peshat, whether in order to derive halakhah from the verse or to weave it into an aggadah (parable or homily). ${ }^{40}$

The sages' exegetical questions are not necessarily identical to those of peshat exegetes, because their underlying assumptions regarding the peshat differed. Sometimes the sages revealed basic, coherent, exegetical assumptions based on linguistic peshat. ${ }^{41}$ There is however another type of midrash that is totally disconnected from the peshat, although it appears to be based upon it. ${ }^{42}$

To conclude, the fundamental difference between the peshat exegetes, scholars, and Bible critics on the one hand, and the sages on the other, is the level of "sincerity" 43 with which they relate to the peshat. The peshat exegetes regard this as the primary and fundamental way of interpreting the Bible, and ascribe enormous significance to its role in the formation of the believer's worldview and perception of reality. The derash exegetes, in contrast, derive their worldview and perception of reality from the Oral Law, and regard the peshat as an additional exegetical option that can never take precedence, either in understanding the Bible or in the formation of the believer's worldview. ${ }^{44}$ Principles of faith and the finer points of halakhah are not determined by their conformity to the plain meaning of the biblical text. On the contrary, by means of derash, the verses are made to conform to the beliefs and opinions, and laws and customs of the Oral Law. This approach allows the sages and those following in their path to relate freely to the peshat and accept the possibility that it contains contradictions and difficulties, both intrinsic and theological.

\section{The "Lower" Criticism of the Sages-Textual Criticism}

Talmudic and midrashic literature reveals the sages' confrontation with textual questions - that is, "lower criticism." 45 The sages understood the differences 
between the Paleo-Hebrew alphabet and the Assyrian alphabet, which they brought back with them from Babylonia. ${ }^{46}$ They were aware of their own lack of proficiency in defective and plene spellings of words, ${ }^{47} \mathrm{knew}$ of the existence of variations between different textual witnesses, ${ }^{48}$ and pointed out the discrepancies between their text of the Torah and the texts of Septuagint ${ }^{49}$ and the Samaritan Torah. 50 There are "scribal emendations" (tikkunei soferim) of the Torah text attributed to the Men of the Great Assembly. ${ }^{51}$ The vocalized letters in the Torah were ascribed to Ezra the Scribe. ${ }^{52}$ In addition to the scribal tradition, there is also an unwritten oral tradition of pronunciation that changed from place to place, and could influence exegesis and homiletics. ${ }^{53}$ Some derashot are based upon variations in vocalization, ${ }^{54}$ and some involve changes in consonants that are in effect textual variants. ${ }^{55}$

Even if the sages regarded one primary text as authoritative according to halakhah and used it to proofread Torah scrolls, they nonetheless recognized the existence of other texts and used them (or even created them) as exegetical and midrashic tools. The disturbing question of whether pointing out textual variations and corrections detracts from the sanctity of the Bible does not seem to have occurred at all to the authors of the midrash, who referred to these matters freely. It is therefore possible to adopt the "relaxed" approach of the sages in response to modern scholars' proposals for emending the biblical text. If the proposal appears reasonable and offers a cogent interpretation of a difficult verse, it can become a midrash in the style of al tikrei ("don't read 'a', read 'b"), ,56 and can be welcomed as an additional interpretation, though not as a potential emendation of the authoritative Masoretic text. ${ }^{57}$

\section{"Higher Criticism"-Dating the Text and Identifying its Author}

The sages discussed the dating of the composition, completion, and editing of the biblical books. Their considerations were similar to those of critical scholars. For example, the examination of linguistic compatibility, the method used by the sages, though not based on modern linguistics, was similar to it in many respects. One of the most important sources for the rabbinic treatment of these issues is the passage in the Babylonian Talmud that discusses the dating of the biblical books. ${ }^{58}$ At the heart of the discussion is a baraita (mishnaic material external to the Mishnah) that lists the authors and editors of the books of the Bible. The Gemara discusses this baraita, searches for explanations for its statements, and disagrees with it, or qualifies it, after an examination of the biblical sources. 
The longest section of the passage is the discussion of the dating and authorship of the book of Job. ${ }^{59}$ The Gemara proposes a wide range of possible time periods for the book's composition, from the time of Moses until the days of the beit midrash in Tiberius at the end of the Second Temple period. The dating of the book was accomplished by means of various kinds of derashot. Some are quasi-linguistic-the discovery of a unique word common to both Job and another verse in the Bible. Some are quasi-historical - the discovery of an event common to both Job and another period in the Bible. Some are topical - the connection between the figure of Job and his actions, and another period in the Bible. Talmudic derashot vary with regard to the proximity of the derash to the peshat. Some linguistic and topical connections appear to be far removed from the peshat, while others are very similar to attempts by modern scholars to date the book of Job. A faith-based argument claiming that it is forbidden to deviate from the early tradition that Job was written by Moses is not raised at any point in the discussion.

The Gemara includes another approach, more "critical" than the others, according to which Job never existed and his story is an allegory. ${ }^{60}$ The Gemara does not take an ideological stand with regard to this approach either, and does not argue that it is forbidden to say that Job is a work of fiction. The discussion focuses on a literary question: Do its many factual details constitute proof of the historical veracity of the story?

The principles that can be derived from this discussion are as follows:

1. The identification of a book's author, date, and place of composition are integral to the task of its interpretation.

2. The identification of a book's author and its time period are not bound by authoritative tradition but rather demand investigation and interpretation by use of various exegetical methods.

3. It is possible to date a biblical book to a later time period, even to the end of the Second Temple period.

4. One of the best ways to ascertain the timeframe and author of a book is a linguistic and topical comparison with parallel biblical texts.

5. Theological considerations are not determining factors in the identification of a book's time period or author.

6. It is possible to propose an interpretation that negates the historical reality of a biblical story and presents it as allegory and fiction. It is, 
therefore, worthwhile to acquire a literary methodology with which to determine if a certain textual unit is realistic or fictitious.

7. Halakhic authority is not to be exercised in this type of discussion; the full range of possibilities remains open.

\section{Higher Criticism-The Division of a Book according to Authors and Time Periods}

The baraita about the order of the biblical canon opens additional possibilities for "criticism" of the biblical corpus, including the possibility of deconstructing one book into different sources. The baraita states that King David, along with "ten elders," wrote the book of Psalms. ${ }^{61}$ Another baraita includes a selection of tannaitic attempts to ascribe the group of psalms known as "hallel miztri" 62 to poets from different periods, from the time of the Exodus from Egypt until the days of Mordecai and Esther. ${ }^{63}$

The following conclusions can be drawn from the discussion of the composition of the book of Psalms:

1. The statement that Kind David wrote the entire book of Psalms is a generalization with many exceptions.

2. It is possible to ascribe psalms to other poets, especially if they lived before the time of King David.

3. It is possible to point to groups of psalms, within the book of Psalms, not written by David but created earlier in the framework of Jewish liturgical poetry and included within the book at the time of its redaction. $^{64}$

In the Middle Ages, the "rabbinic" approach to the integrity of the book of Psalms and its antiquity was polarized. On one extreme stood Saadya Ga'on, who argued that the entire book, including its futuristic and prophetic chapters, was the word of God to King David. On the other extreme, Rabbi Moses ha-Kohen ibn Gikatilla dated certain psalms to as late as the time of the Return to Zion. ${ }^{65}$ It is reasonable to assume that the resolute position of Saadya Ga'on with regard to the antiquity, integrity, and divine origin of the book of Psalms is connected to his involvement in the polemic against the Karaites. Rabbi Moses ibn Gikatilla's approach, on the other hand, is compatible with the sages' tolerant and relaxed discussion of the dating and sources of the book of Psalms. ${ }^{66}$ 


\section{Higher Criticism: The Distinction between the Composition of a Book and its Editing and Canonization}

Another critical feature that clearly emerges from the discussion in the Babylonian Talmud, tractate Bava Batra, about the editing of the biblical books is the sages' distinction between the principal author of a book, its final editor, and other editors. The baraita declares that Joshua must have written the last eight verses of the Torah because it is impossible that Moses wrote the words, "So Moses the servant of the Lord died" (Deut. 34:5) and the following verses. The baraita expresses a similar opinion regarding other biblical books that were completed by later authors or editors. It attributes the books of Isaiah, Proverbs, the Song of Songs, and Ecclesiastes to "Hezekiah and his group" rather than to the prophet Isaiah and King Solomon, despite the fact that the books ascribe themselves to these authors. The baraita attributes the books of Ezekiel, the Twelve Minor Prophets, Daniel, and Esther to the Men of the Great Assembly, in other words to the period of the Second Temple, despite that fact that several of them, including the early minor prophets, were written much earlier. This baraita was not accepted as an authoritative source. There are those who disagreed with it and maintained that Moses wrote the concluding verses of the Torah, even though this means that he recorded his own death. They did not, however, argue that it is heretical to believe that a section of the Torah was not written by Moses, but rather explained their reasoning with exegetical arguments. When the Gemara allowed the possibility, on the one hand, of disagreeing with the baraita about the editing of Bible, and, on the other hand, of using rational considerations to date the book, it paved the way for all modern critical discussion about the editing of the biblical corpus. ${ }^{67}$

\section{The Sanctity of the Biblical Books-Theological Difficulties}

The Mishnah, in tractate Yadayim, records an argument among the sages on the question of which books "defile the hands." ${ }^{68}$ It is accepted that this discussion reflects the historical process of the canonization of the Bible. Even if the discussion has conceptual rather than historical validity, it testifies to the positions of the sages discussing the question of what should and should not be included in the biblical canon. ${ }^{69}$ The sages questioned the sanctity of Ecclesiastes, Song of Songs, and Esther. They also discussed the possibility of excluding books from the canon: Ecclesiastes, because it contains internal inconsistencies, and 
ostensibly heretical ideas and contradicts the Torah; Proverbs, because of its internal inconsistencies; and Ezekiel, because it contradicts the Torah.

The principle that emerges from these discussions is that there is no valid, authoritative, early rabbinic source that invests the books of the Bible with inherent and absolute sanctity. The decision that one book would enter the canon (and thus "defile the hands") while another would be excluded from it, condemned to oblivion or even banned, was determined by the sages' assessment of the general worth of the book and its educational and practical efficacy. They also took into consideration the possible use of creative interpretation to solve problems that could arise during study, in order to prepare the book for study by the general public. Because the source of the validity and sanctity of the books lies not in their authors or their manner of composition but in the halakhic ruling of the sages, there is no reason to fear that a critical examination of them will impinge upon their sanctity. ${ }^{70}$ The critics will raise questions, and peshat and derash exegetes will answer them, in their different ways, but nonetheless, the book will retain the sanctity invested in it by the halakhah, as determined by the sages. If these same researchers "discovered" that the Torah scroll is made out of cowhide and written in gall ink, would its sanctity be diminished in any way?

\section{The Documentary Hypothesis}

After generations of controversy surrounding the documentary hypothesis, Alexander Rofé summarized the approach of contemporary modern research to this theory in four principles: (a) There are serious difficulties in the sequence of the biblical narrative; (b) These difficulties were created by the redaction of different sources; (c) It is possible to identify these various sources by means of comparative analysis of style and content; (d) It is possible to date approximately, and sometimes even definitely, the creation of some of the sources that have been identified. ${ }^{71}$

Many biblical scholars have rejected the documentary hypothesis. Some did so from "within," using the same premises and methodology as the authors of the hypothesis in its various forms. ${ }^{72}$ For their part, many religious Jews have rejected the hypothesis from "outside" because it contradicts the basic principle of faith, that the entire Torah was given to Moses from heaven as a single unit.

The principles of the documentary hypothesis are not entirely foreign to the world of the sages. The midrash raises problems and solutions that are similar to those of the critics. First of all, the sages clearly acknowledged 
the existence of inconsistencies in the text and were not frightened by them. On the contrary, the hermeneutic principle "two verses that contradict each other" is a fundamental principle of midrash. Hundreds of midrashim are structured in the framework of the juxtaposition of contradictory sources: "One verse says ... another verse says ...."

Not infrequently, the contradiction between verses is resolved by reexamining each verse in its context: "Here, when they are doing the will of God, and there, when they are not doing the will of God"; 73 "This refers to a time when the Temple is standing, and that to a time when it is not standing."74 Distinctions along the lines of "Here, when ... there, when ...," which understand contradictory verses as reflecting different historical periods or spiritual states, are very common. This does not mean that the sages believed that these verses were written at different times. They were, however, clearly indicating that the verses must be read as referring to different periods and reflecting the differences between them. ${ }^{75}$

The concept of source criticism is also expressed in midrashim declaring that two contradictory verses were said "in a single utterance." 76 The solution, expressed by means of the verse "One thing God has spoken; two things have I heard" (Ps. 62:12), ${ }^{77}$ does not attempt to resolve the contradiction, but rather accepts the possibility that the Torah includes contradictory verses, each of which has its own meaning in its own context.

Rabbi Mordecai Breuer accepted the documentary hypothesis as the correct way to solve difficulties in the Torah. He was not able, however, to accept its theological implications, and therefore confronted the theological problem raised by biblical criticism in the same way that the sages wrote midrash. He accepted the tools of critical analysis, and used them to explain the Torah without committing himself to any superficial conclusions regarding the sources of the sacred text. Rabbi Breuer even regarded his method as "midrash." He believed that the Torah was given by God to Moses as a single integral unit, yet it can be interpreted as if it were compiled from various sources. ${ }^{78}$

According to Breuer's approach, the Torah reflects "two aspects": "mercy" and "judgment." One uses the Tetragrammaton, the other Elohim; one describes festivals from a sacral perspective, and the other from a social/national perspective. This approach raises the possibility of including within the variations in aspects reflections of historical and cultural differences. In Genesis, the Torah uses the language of the Patriarchs; in Deuteronomy, the language of the kings; in Leviticus, the language of the priests; and in Exodus, the language of the people. ${ }^{79}$ 


\section{History and Chronology}

I will now turn to the question of the historical authenticity of the Bible.

There is a contradiction between the prohibition of erecting a stone pillar given in Deuteronomy and references to stone pillars that were erected in the days of the Patriarchs. The sages' solution to this problem is that the stone pillar, popular among the Patriarchs, became hateful to their descendants because of a change in circumstances. ${ }^{80}$ Thus, significant contradictions between verses in the area of beliefs and opinions, or halakhic and ethical practice, can be resolved by historical distinctions. The contradiction can be explained as a change that occurred during the giving of the Torah, from the mouth of God, or as the result of changes that occurred, or were going to occur, in the cultural environment.

The traditional approach to biblical chronology gave particular weight to early rabbinic midrash at the expense of the simple meaning of the verses. The result was that even traditional peshat exegetes found it difficult to grasp that the chronologies developed by the sages were, in fact, derashot. They therefore attempted to reconcile them with the simple meaning of the text. ${ }^{81}$ For example, midrash Seder Olam Rabbah, attributed to Rabbi Yose ben Halafta, became accepted as an authoritative chronology even by the peshat exegetes. As a result, they attempted to justify the historicity of the chronologies even when they appeared to be completely fictitious derashot, ${ }^{82}$ or totally contradicted what was known from other chronological sources. ${ }^{83}$ In truth, like any other midrashim, the sages arrived at the biblical timeline in their own way, the way of derash.

In the Zohar, it is made very clear that biblical stories are not to be read as historical narrative. ${ }^{84}$ This book nullified the requirement to accept the literal historical dimension of biblical stories as necessarily true, and thus opened the door to an ahistorical exegesis that examines what can be learned from the verses conceptually without regard for their historical context. At the same time, it can be understood from the Zohar that historical exegesis is also acceptable, as long as it does not negate the compelling spiritual meanings of the verse. Just as the peshat did not determine the historical understanding of the sages, the derashot of the sages do not define history. Neither are damaged when new interpretations based on historical methodology and current historical knowledge are proposed. This has been the task of commentators throughout the generations. Their work should not be obstructed for fear 
of undermining the sanctity of the Torah or the importance and value of the words of the sages when they do not conform to contemporary historical perspectives.

\section{When was the Torah Given and When was it Written?}

According to the simple meaning of the biblical text, after the Ten Commandments were given to Moses on Mount Sinai, he studied the Torah for forty days on the mountain, and then taught it to the People of Israel. Over the course of their subsequent journey through the desert, Moses received additional parts of God's Torah. On the plains of Moab, he explained the contents of the Torah, and these words form the basis of the book of Deuteronomy. ${ }^{85}$ Just before he died, Moses completed the Torah, wrote it down as a book, and gave it to the People of Israel. ${ }^{86}$

The question of whether the Torah was written by Moses by hand is not necessarily synonymous with the question of the divine origin of the Torah. According to the Midrash, Korah first challenged the divine origin of Moses' Torah, although he clearly did not refute that the Torah was given by Moses. ${ }^{87}$ On the other hand, the expression Torah min ha-shamayim (Torah from heaven) is not limited only to the Torah of Moses. The Oral Torah, at least that part that is based upon the Written Torah, is also considered to be of divine origin, as the Talmud states: "Even if he said, 'The entire Torah is from heaven, except for this point that is deduced by extrapolation (kal va-homer) or analogy (gezerah shavah),' he is still included in the verse, 'Because he has spurned the word of the Lord and violated His commandment, that person shall be cut off-he bears his guilt"' (Num. 15:31). ${ }^{88}$

The definition of the concept "from heaven" (of divine origin) in the context of the Oral Law, requires a separate discussion, along theological lines. ${ }^{89}$ The tension between "from heaven" and "it is not in the heavens" (Deut. 30:12) is reflected in the aggadah concerning Akhnai's oven that has occupied generations of commentators. ${ }^{90}$ The sages believed it possible both to reject the divinity of the Torah while standing beside Moses on Mount Sinai, and to consider new ideas originating in the beit midrash of the sages, even if they are controversial, as "Torah from heaven": "both are the words of the living God." 91 The saying, "Anything that an advanced student will teach in the presence of his master was already said to Moses on Sinai," 92 is not a paradox or a contradiction in terms if the words "will teach" and "to Moses on Sinai" are not understood literally. 
Religious people confronted by critical research are deeply disturbed by the chronological and historical timeline of the giving of the Written Torah. This seems to be the most difficult challenge to religious faith posed by academic biblical scholarship. However, the sages would, it seems, not have condemned someone as a heretic for believing that the book known as "the Torah of Moses" originated on Mount Sinai, developed over the generations, and was completed only at the beginning of the Second Temple period, as long as that person believed it to be "Torah from heaven"-meaning sacred, divine, and binding on belief and practice.

This subject can be compared to Maimonides' negation of God's corporality. Maimonides argued that all the verses that contain a reference to the corporality of God should be interpreted otherwise. He devoted a significant part of The Guide of the Perplexed to validating his approach on principle, and using it to reinterpret the Bible. On the basis of this approach, Maimonides declared that the angels revealed to the Patriarchs in Genesis were prophetic visions rather than real entities, and he was severely attacked for it. ${ }^{93}$ Maimonides survived the bitter attacks against his philosophical and exegetical approach, and remains one of the greatest authorities of all times, not only in halakhah but also in Jewish thought. Maimonides also stated (and he was not alone in doing so) that if, by means of the rational and scientific tools of his time, he had arrived at the conclusion that the world is eternal, he could have reinterpreted the Torah by means of derash, and explained the verses describing creation in accordance with this belief. ${ }^{94}$ Applying Maimonides' approach to the composition of the Torah, it can be assumed that it is possible to interpret the verses that describe Moses writing the Torah in such a way as to separate them from their plain meaning, although they would nonetheless continue to be the cornerstone of the belief in the divine origin of the Torah.

\section{Conclusion}

In this article I have argued that modern academic biblical criticism should be treated as an additional branch of biblical exegesis. Though a product of the relatively recent past, it is an extension of the broad and well-established genre of rabbinic midrash. While the early academic scholars of Judaism attempted to find a source for their analytical approach in the methodology of the medieval peshat exegetes, I have suggested that biblical scholarship should be seen as an approach based on the traditional midrashic methodology of the sages, as it has been continued in derash-based literature throughout the subsequent generations. 
The approach that declares biblical scholarship to be the continuation of medieval peshat exegesis creates tension. It claims to represent the fundamental exegetical truth, and creates a direct correlation between the "correct" understanding of the pesaht and the foundation of beliefs and opinions on the Bible, revelation and prophecy. This is not the case if we approach biblical scholarship from the liberal spirit of rabbinic midrash. Beliefs and opinions, as well as ethical principles and halakhah, are grounded in variety of sources in halakhah and aggadah, authenticated by the sages of the Oral law, while the field of Bible study, including the academic and critical approach, is left open to the "interpretations that are being discovered every day." 95

\section{Endnotes}

1. J. M. Grintz, Mevo'ay Mikra [Introductions to the Bible] (Tel Aviv: Yavneh, 1972), 158-181; Hava Lazarus-Yafeh, Intertwined Worlds: Medieval Islam and Bible Criticism (Princeton: Princeton University Press, 1992). On Muslim influence on the Karaites, see Yoram Erder, Avlei Tzion ha-Kara'im u-Megilot Kumran: Le-Toldot Halufa le-Yahadut ha-Rabanit [The Karaite mourners of Zion and the Qumran scrolls: The history of an alternative to rabbinic Judaism] (Ra'anana: Hakibbutz Hameuchad, 2004), 355-364; Mordechai Cohen, "Mekor Sefaradi Efshari le-Tefisat 'Peshuto shel Mikra' etzel Rashi” [A possible Sephardic source for Rashi's understanding of "peshuto shel mikra"], in Rashi: Demuto ve-Yetzirato: Mekorotav shel Rashi ve-Haspha'ato [Rashi: His image and works: Rashi's sources and his influence], ed. Sara Japhet and Avraham Grossman (Jerusalem: Zalman Shazar, 2009), 2:353-379. On the Christian influence on peshat exegesis, see Joseph Dan, "Midrash: Me-Parshanut le-Anarkhia" [Midrash: From exegesis to anarchy], in Devarim u-Shivrei Devarim [The Jewishness of Israel], ed. Aviezer Ravitzky and Yedidia Z. Stern (Jerusalem: Israel Democracy Institute, 2007), 237-279. On the essential difference between the classical rabbinic pattern of thought and Greek patterns of thought that were absorbed into Jewish thought from the beginning of the gaonic period, see also Yitzhak Ezuz, Meharsai' ikh u-Meharivai'ikh me-Ohavai'ikh Yetzu [Thy destroyers and they that made thee waste shall come from amongst your lovers: On the process of the dissolution of the Jewish in the Western (from paradigm to "reasonable possibility")] (Tel Aviv: Mofet Institute, 2012).

2. This article refers to the sages as a single unit only for the purposes of the discussion. Although the sages differed in their approaches to Bible and midrash, in order to argue that a particular approach enjoyed official rabbinic legitimacy it is sufficient to show it was accepted by some of the tannaim and amoraim, and preserved in the Talmuds and the classical midrash.

3. Judah Rosenthal, "She'elot Atikot be-Tanakh" [Ancient questions about the Bible], Hebrew Union College Annual 21 (1948): 29-91.

4. Grintz, Mevo'ay Mikra, 38-48; Menahem Haran, Ha-Asufa ha-Mikrait [The biblical collection] (Jerusalem: Mosad Bialik, 1996), pt. 1A; Abraham Kahana, Ha-Sefarim ha-Hizoni'im [The Apocrypha], vol. 1, Mavo Klalli le-Sefarim ha-Hitzoni'im [General introduction to the Apocrypha] (Jerusalem: Makor, 1970), 7-10.

5. Eliezer Rosenthal, "Ha-Moreh" [The Teacher], Proceedings of the American Academy for Jewish Research 31 (1963): i-vxxi. 
6. Moshe Katz, "Yesh Shishim Ribo Otiot le-Torah, ha-Amnam?" [Are there really six hundred thousand letters in the Torah?], Tehumin 21) 2001): 555ff.

7. Jerusalem Talmud, tractate Ta'anit 4:2, 68a.

8. Bereshit Rabbah 20:12.

9. Babylonian Talmud, tractate Megillah 9a-b

10. Babylonian Talmud, tractate Sukkah 35a, inter alia.

11. Babylonian Talmud, tractate Pesahim 61a; Jerusalem Talmud, tractate Sotah 7:2, 21c.

12. Babylonian Talmud, tractate Sanhedrin $4 \mathrm{~b}$.

13. Babylonian Talmud, tractate Rosh Hashanah 26a. It would appear that this is an exegetical method typical of Rabbi Akiva, who used foreign words that he learned on his travels to "Arabia," "Gaul," and "Africa."

14. The Torah was given on Sinai in four languages. Sifrei Devarim, piska 343.

15. Babylonian Talmud, tractate Avodah Zarah 58b, inter alia.

16. Babylonian Talmud, tractate Shabbat 115a-b, inter alia.

17. Primarily in Seder Olam Rabbah. See Anat Reizel, Mavo le-Midrashim [Introduction to the midrashic literature] (Alon Shvut: Herzog College, 2011), 305-314.

18. Emanuel Tov, Bikoret Nusah ha-Mikra [The textual criticism of the Bible: An introduction] (Jerusalem: Mosad Bialik, 1989), 11-12.

19. Babylonian Talmud, tractate Kiddushin 30a.

20. Eliezer Schweid, Toldot Pilosofiat ha-Dat ha-Yehudit be-Zeman he-Hadash [A history of modern Jewish religious philosophy] (Ra'anana: Am Oved, 2002), pt. 2, 95-143.

21. Moshe David Herr, "The Historical Significance of the Dialogues between Jewish Sages and Roman Dignitaries," Scripta Hierosalymitana 22 (1971): 123-150.

22. Chayuta Deutsch, "Ha-Matrona Rabat ha-Panim" [Encounters between sages and matrons: Fixed patterns and variations], PhD diss., Bar Ilan University, 2011.

23. E.g., Turnus Rufus (Bereshit Rabbah 11:5) and Adrianus (Bereshit Rabbah 28:6). See Ido Hevroni, "Brit Milah ke-Mered" (Brit Milah as rebellion), Tekhelet 28 (2007): 61-73.

24. Jerusalem Talmud, tractate Shabbat 3:3, inter alia.

25. Mishnah, tractate Hagigah 2:1. Tosefta, Megillah 3:31-35. See Yehuda Brandes "Bemai Kamipalgi: le-Mahloket Ha-Aharonim be-Parshanut Heto shel David” [What is this argument about?: The controversy among contemporary scholars over the interpretation of the sin of David], Megadim 26 (1996): 107-127.

26. Rabbi Aharon Lichtenstein, "U-be-Yad ha-Nevi' im Adameh: Nituah Sifruti ve-Kitvei ha-Kodesh" ["And spoke parables through the prophets": Literary analysis and the Bible], in $\mathrm{Hi}$ Sihati: Al Derekh Limmud ha-Tanakh [It is my study], ed. Yehoshua Rice (Alon ShevutJerusalem: Yeshivat Har Etzion and Sifrei Maggid, 2013), 73-82.

27. "The story of modern bible scholarship is thus essentially a Protestant story. ... It can be said that the order is reversed, atheist biblical criticism began as it were with Spinoza." James Kugel, "Heker ha-Mikra le-Toldotav" [The history of biblical scholarship], in Sifrut ha-Mikra: Mevo'ot u-Mehkarim [The literature of the Hebrew Bible: introductions and studies], ed. Zipora Talshir (Jerusalem: Yad Ben-Zvi, 2011), 1:18, n. 22.

28. "We have to reject deliberate tendentiousness and at least attempt to overcome our biases when we examine historical questions." Alexander Rofé, Mavo le-Sifrut ha-Mikra [Introduction to the literature of Hebrew Bible] (Jerusalem: Carmel, 2006), 16.

29. Evidence of this can be found in the success of the peshat "revolution" in the period of the Rishonim (the Middle Ages). Rashbam (Samuel ben Meir), for example, lived in two worlds, and did not see a contradiction between them. He was a commentator on the Talmud, a scholar of halakhah and a Tosafist. As a biblical exegete, he was firmly entrenched in the 
world of the Sephardic peshat exegetes and created many of the new peshat interpretations (that were, in his words, appearing daily) without committing himself to the interpretation of the sages or that of his grandfather, Rashi.

30. Babylonian Talmud, tractate Hagigah $15 \mathrm{~b}$.

31. The tendency to base the principles of faith on the peshat exegesis of the Bible, while distancing them from the sages' method of midrash, is closely connected to the influence of Greek-Arabic philosophy on the Ge'onim. See Robert Brody, Rav Se'adya Gaon (Jerusalem: Zalman Shazar, 2006), 70-90.

32. Babylonian Talmud, tractate Shabbat 13b.

33. Ze'ev Levy, Hermeneutica be-Mahshevet ha-Yehudit be-Et ha-Hadasha [Hermeneutics in Jewish modern thought] (Haifa: University of Haifa, 2006), 25-34 and 67-86.

34. Sara Japhet, Dor Dor u-Parshanav: Asufat Mehkarim be-Parshnut ha-Mikra [Collected studies in biblical exegesis] (Jerusalem: Mosad Bialik, 2008), 35-54; Shalom Rosenberg, "Ben Peshat le-Derash" [Between peshat and derash], De'ot 37 (1969): 91-99; Rabbi Mordechai Breuer, "Limud Peshuto shel Mikra: Sakanot ve-Siku'im" [Studying the peshat of the Bible: Risks and chances], Ha-Ma'ayan 18 (1978): 1.

35. This is the meaning of the aggadah that describes the astonishment of Moses at the insights that Rabbi Akiva derived from his Torah (Babylonian Talmud, tractate Menahot 29b).

36. Babylonian Talmud, tractate Eruvin 23b and parallels. The sages differ in this respect from the derash and faith-based approaches that ascribe no value to the peshat, but rather regard the entire Torah as a type of code to reveal hidden secrets.

37. Babylonian Talmud, tractate Shabbat 63a.

38. Babylonian Talmud, tractate Bava Kamma 83b-84a. Rabbi Solomon Luria (Maharshal) in his commentary on these passages discussed the question of whether the sages interpreted the verses according to their own halakhic preconceptions, or whether their derashot shaped the development of the halakhah. See his commentary Yam shel Shlomo, Bava Kamma, chapter 8, siman 1. See also Shalom Rosenberg, Lo ba-Shamayim Hi: Torah She-be-al peh: Masoret ve-Hidushim [It is not in heaven: Oral Law: Tradition and reinterpretation] (Alon Shvut: Tevunot, 1997), 9-53.

39. Rabbi Abraham Isaac Kook distinguished between these two types of derashah by means of a theoretical distinction between explanation and exegesis. See his introduction to Ein Ayah: Al Aggadot Hazal she-ba-Ein Yaakov (Jerusalem: Ha-Makhon al shem ha-Ratziyah Kook, 1986), tractate Berakhot. See also Hananel Mack, Ha-Parshanut ha-Keduma le-Mikra [The early commentary to the Bible] (Jerusalem, Ministry of Defense, 1993), 11-16.

40. Isaac Heinemann, Darkhei Ha-Aggadah (Jerusalem: Magnes, 1950), 1-13 and 153-157.

41. This is the fundamental approach of Rabbi Akiva. Shmuel Safrai, Rabbi Akiva ben Yosef, Hayyav u-Mishanto [Rabbi Akiva ben Yosef: His life and teachings] (Jerusalem: Mosad Bialik, 1970), 50-55.

42. Tosafot commentary on Babylonian Talmud, tractate Kiddushin 2b, s.v. kashu k'ra'i: "Nevertheless, wherever it is possible to explain this, the Gemara does so."

43. In the words of Isaac Heinemann, Darkhei Ha-Aggadah, 186-195.

44. Umberto Cassuto is attributed with the insight of understanding biblical criticism as one of the seventy facets (or faces) by which the Torah is interpreted.

45. Yeshayahu Maori, “Midrashei Hazal ke-Edut le-Hilufei Nusạ̣ ha-Mikra” [rabbinic midrash as evidence of textual variations in the Bible], in Iyunei Mikra u-Parshanut [Studies in Bible and exegesis], ed. Moshe Bar-Asher et al. (Ramat Gan: Bar Ilan University, 1993), 3:267-286; David Rosenthal, "Al Derekh Tipulam shel Ḥazal be-Ḥilufei Nusaḥ be-Mikra” [The sages' treatment of textual variations in the Bible], in Sefer Yitzhak Aryeh Zeligman: Ma'amarim be-mikra u-va-Olam he-Atik [Isaac Leo Seeligman Anniversary Volume: Essays in Bible and 
the ancient world], ed. Yair Zakovitch and Alexanader Rofé (Jerusalem: Rubenstein, 1983), 2:395-417; Zipora Talshir, "Le-Toldot Nusah Ha-Mikra" [The history of the biblical text], in Sifrut ha-Mikra: Mevo'ot u-Mehkarim, 1:38-48.

46. Babylonian Talmud, tractate Sanhedrin 21b-22a; Rosenberg, "Ben Peshat le-Drash," 28-36.

47. Babylonian Talmud, tractate Kiddushin 30a.

48. Daniel Sperber, Netivot Pesika [Paths of pesika: methods and approaches for proper halakhic decision making] (Jerusalem: Reuven Mas, 2008), 72 and n. 120 there.

49. Masekhet Soferim 1,7.

50. The sages explained the discrepancies between their Torah and the Samaritan Torah as the result of forgery. Babylonian Talmud, tractate Sotah 33b, and parallels.

51. In the midrash, the corrections are attributed to the Men of the Great Assembly. Tanhuma Shemot, 16.

52. Avot de-Rabbi Natan, nusah B, chap. 37. Ba-midbar Rabbah 3, 13, indicates that Ezra wrote the text of the Bible and in doing so also added the vowel signs.

53. The interchange of alef and ayin (Babylonian Talmud, tractate Berakhot 32a); hey and het (ibid., 30b). See Jerusalem Talmud, tractate Shabbat 7:2, $9 \mathrm{~b}$ on the legitimacy of interchanging hin and hitin.

54. For example, harut (engraved) and herut (freedom). Avot de-Rabbi Natan, nusah A, chap. 2.

55. For example, shibbarta (you broke)-shirbabta (you stretched out), Babylonian Talmud, tractate Berakhot 54b; ain biltekha ("there is none beside You" [1 Sam. 2:2])-ain lebalotekha ("you cannot be consumed"). Ibid., 10a, inter alia.

56. Naftali Herz Tur-Sinai, "Al Tikrei," Entzeklopedia Mikrait [Encyclopaedia biblica] (Jerusalem: Mosad Bialik, 1950-1988) 1:420-422; Henoch Yalon, Pirkei Lashon [Essays on linguistics] (Jerusalem: Mosad Bialik, 1971), 123-125.

57. On Levinas' opinion of the role of midrash, see Elizabeth Goldwyn, Revah ben ha-Otiot: Shiurav ha-Talmudi'im shel Levinas: Hatama ben Tokhen ve-Tzura [Space between the letters: Emmanuel Levinas' talmudic readings between form and content], ed. Yoram Vereté (Bnei Brak: Amutat Hillel ben Hayyim, 2011).

58. Tractate Bava Batra 15a.

59. Hananel Mack, Ele Mashal Haya: Iyov beinei Hazal [It was a metaphor: Job in the eyes of the sages] (Ramat Gan: Bar Ilan University, 2004).

60. There are modern scholars who interpret other books, such as Jonah and Esther, in this manner.

61. Babylonian Talmud, tractate Bava Batra 14b-15a.

62. Ps. 113-118.

63. Babylonian Talmud, tractate Pesahim 117a

64. According to the methodology of Hermann Gunkel, who identified sections of the Bible according to their genre, and Umberto Cassuto, who revealed ancient poetry integrated within the later biblical books.

65. Ps. 137 ("By the rivers of Babylon ...") is described in the Gemara as a prophetical psalm by King David (Babylonian Talmud, tractate Gittin 57b). However, the midrashim on Lamentations indicate that Jeremiah and the exiles to Babylon wrote the psalm (Midrash Zuta, ed. Shlomo Buber [Vilna: Rem, 1925] parasha 1, piska 19).

66. Uriel Simon, Arbah Gishot le-Sefer Tehillim [Four approaches to the book of Psalms] (Ramat Gan: Bar Ilan University, 1982).

67. It is important to distinguish between discussion of the books of the Prophets and the Writings, and discussion of the five books of the Torah of Moses. The dating of the Torah to the time and place of Moses is the cornerstone of the belief in its divine origin. I will return to this point below. 
68. Mishnah, tractate Yadayim 3:8. Paradoxically, the sages ordained that it was holy books that render one ritually unclean, in order to prevent people from putting terumah (a food offering) next to the books and damaging them thereby.

69. Haran, Ha-Asufa ha-Mikrait, pt. 1, 201-303.

70. Grintz, Mevo'ay Mikra, 30-48.

71. Rofé, Mavo le-Sifrut ha-Mikra, 112.

72. See, e.g., M. H. Segal, Mavo ha-Mikra [Introduction to the Bible] (Jerusalem: Kiryat Sefer), 127-147.

73. Babylonian Talmud, tractate Yoma $3 \mathrm{~b}$.

74. Babylonian Talmud, tractate Hagigah 13b.

75. There are those who see in the idea that "the Torah was given in sections" (Babylonian Talmud, tractate Gittin 60a-b) the initial nucleus of the concept of identifying various documents within the Torah.

76. Jerusalem Talmud, tractate Nedarim 3:2.

77. Babylonian Talmud, tractate Sanhedrin 34a.

78. Yosef Ofer, ed, 'Shitat ha-Behinot' shel ha-Rav Mordekhai Breuer [The aspects theory of Rabbi Mordechai Breuer] (Alon Shvut: Tevunot, 2005).

79. David Zohar, Mehuyavut Yehudit ba-Olam Moderni: ha-Rav Hayyim Hirschensohn ve-Yahaso el ha-Moderna [Jewish responsibility in the modern world: Rav Hayyim Hirschensohn and his approach to modernity] (Jerusalem: Shalom Hartman Institute, 2003), 277-283.

80. Deut. 16:22. In contrast to Gen. 28:18, inter alia. Igrot ha-Ra'aya [The letters of Rabbi Abraham Isaac Ha-Kohen Kook] (Jerusalem: Mosad Harav Kook, 1961-1965) 3:746.

81. Rabbi Hayyim Hirschensohn argued that the chronology of the sages is binding according to the halakhah, despite the fact that it is based on derash and serves theological objectives. However, the halakhic requirement applies to dating a get (certificate of divorce) or calculating sabbatical and Jubilee years. It is not relevant to a historian writing the history of the world. See Zohar, Mehuyavut Yehudit, 236.

82. For example, the midrash that Isaac married Rebekah when she was three years old (see Rashi's commentary to Gen. 25:20). While Rabbi Eliyahu Mizrahi attempted to explain the feasibility of this midrash, Isaac Abravanel rejected it because of its improbability. The Tosafot expressed the opinion that she was fourteen at the time of her marriage. It is possible that they had a variant text of Seder Olam Rabbah (chap. 1).

83. In Seder Olam Rabbah the length of the Persian period of the era of the return to Zion is much shorter than the chronology accepted by historians. See Hayyim Hafetz, "Malkhut Paras u-Madai ba-Tekufat Bayit Sheni u-lefaneha: Iyun Mehudash” [The Persian and Median kingdom in the Second Temple period and before: A new examination], Megadim 14 (1990): 78-147. See also the comments of Rabbi Yaakov Medan "Mavo le-Ma'amro shel H. Hafetz al Malkhut Paras u-Madai” [Introduction to H. Hafetz's article on the Persian and Median kingdom], Megadim 14 (1990): 47-77.

84. Zohar, part 3, parashat Be-ha'alotekha, 149a-b.

85. Deut. 1:1, and the Sifrei there.

86. In Exodus 24:4, Moses writes down the commandments. In Numbers 33:2, he records the journeys in the desert. In Deuteronomy 31:9, he writes down the Torah and gives it to the priests. In Deuteronomy 31:22, he writes his poem.

87. Jerusalem Talmud, tractate Sanhedrin 10:1, 27d.

88. Babylonian Talmud, tractate Sanhedrin 99a.

89. Maimonides included belief in the divine origin of the Torah in his thirteen principles of faith. The meaning of the concept as it appears in various places in his own writings requires 
close examination. Mark B. Shapiro, The Limits of Orthodox Theology: Maimonides' Thirteen Principles Reappraised (Oxford: Litman, 2004), 91-121. See also Shlomo Kassierer and Shlomo Glicksberg, Mi-Sinai le-Lishkat ha-Gazit: Torah she-be-al peh be-mishnatam shel ha-Rambam ve-ha-Ramban [From Sinai to Sanhedrin: The Oral Law in the thought of Maimonides and Nachmanides] (Ramat Gan: Bar Ilan University, 2007).

90. See Izhak Englard, “Tanuro shel Akhnai': Perusheiha shel Aggadah” [The oven of Akhnai: Interpretations of the aggadah] Shnaton ha-Mishpat ha-Ivri 1 (1974): 45-50.

91. Babylonian Talmud, tractate Eruvin 13b.

92. Jerusalem Talmud, tractate Pe'ah 2:4, 17a, inter alia.

93. For example, Nachmanides' commentary to Gen. 18:1.

94. The Guide of the Perplexed, 2:25. Rabbi Abraham Isaac Ha-Kohen Kook wrote in a similar vein with regard to the idea of evolution. See his Orot ha-Kodesh (Jererusalem: Mosad Harav Kook, 1964), 2:542. See also Rabbi Amit Kula, Havaya o lo haya [Existential or nonessential: History and literature, religious language and the nature of deity] (Jerusalem: Ha-Kibbutz ha-Dati, 2011), 68-74. Rabbi Kula's book in its entirety addresses the question of the historicity of the Torah. Exegetes from Rabbi Isaac the Blind to modern thinkers perceived the Written Torah as a type of Oral Torah. See Alexander Even Chen, Akedat Yitzhak: Be-Parshanut ha-Mistit ve-ha-Pilosofit shel ha-Mikra [The Binding of Isaac: Mystical and philosophical interpretation of the Bible] (Tel Aviv: Mishkal, 2006), 11-13; and Tamar Ross, Expanding the Palace of Torah: Orthodoxy and Feminism (Hanover, NH: Brandeis University Press, 2004), 163-224.

95. See the comment by Rabbi Samuel ben Meir (Rashbam) on Gen. 37:2. 